\title{
Are we near to the end of the standard dose of micafungin?
}

\author{
Alexander Agrifoglio* [D, Lucía Cachafeiro, Eva Herrero, Manuel Sánchez and Abelardo García de Lorenzo \\ See related research by Maseda et al., https://ccforum.biomedcentral.com/articles/10.1186/s13054-018-2019-8
}

Keywords: Micafungin, Pharmacokinetic, Candida

We have carefully read the study titled "Population pharmacokinetics/pharmacodynamics of micafungin against Candida species in obese, critically ill, and morbidly obese critically ill patients" [1] and congratulate the authors for such an interesting initiative.

The researchers conclude the lack of adequate micafungin exposure with a $100 \mathrm{mg} / 24 \mathrm{~h}$ dose regardless of the Candida species or the patient's weight. Further, micafungin exposure was adequate to cover Candida albicans with a $150 \mathrm{mg} / 24 \mathrm{~h}$ dose for patients weighing up to $115 \mathrm{~kg}$ and with a $200 \mathrm{mg} / 24 \mathrm{~h}$ dose for those surpassing this weight. The $200 \mathrm{mg} / 24 \mathrm{~h}$ dose covered Candida glabrata for patients weighing up to $115 \mathrm{~kg}$.

These results could correlate with, and also support those that we previously obtained in the first study [2] published on the pharmacokinetics (PK) of micafungin in plasma and burn eschar tissue in critically ill patients with severe burn injuries, which were compared with the PK of micafungin in patients with intra-abdominal infections [3]. In our study, 15 burn patients were compared with ten patients with intra-abdominal infection; all patients were treated with 100 to $150 \mathrm{mg} /$ day of micafungin.

We also observed that the standard dose of micafungin, $100 \mathrm{mg} /$ day, achieves optimal PK/pharmacodynamics (PD) targets in plasma for MIC values of $0.008 \mathrm{mg} / \mathrm{L}$ and $0.064 \mathrm{mg} / \mathrm{L}$ for non-parapsilosis Candida spp. and Candida parapsilosis, respectively. By increasing the dose to $200 \mathrm{mg} /$ day, the optimal PK/PD targets in plasma could be achieved for MIC cutoff values that are twofold higher $(0.016 \mathrm{mg} / \mathrm{L}$ and $0.125 \mathrm{mg} / \mathrm{L}$, respectively).

\footnotetext{
* Correspondence: alexander_agrifoglio@yahoo.es Department of Intensive Care Medicine, Hospital Universitario La Paz, Paseo de la Castellana 264, 28046 Madrid, Spain
}

To these subpopulations of critically ill patients we must add patients with sepsis and mechanical ventilation [4]. The authors recommended dose of $100 \mathrm{mg} /$ day of micafungin would be associated with a very low probability of reaching the $\mathrm{AUC}_{0-24} / \mathrm{MIC}$ ratio in cases of infection with C. albicans or C. glabrata with $\mathrm{MIC} \geq 0.015 \mathrm{mg} / \mathrm{L}$, as well as in almost all cases of infection due to C. parapsilosis.

Finally, the conclusions presented above in relation to the most recent PK studies of micafungin, performed in different subpopulations of critically ill patients, would provide us with significant evidence that we should consider an increase in the standard dose $(100 \mathrm{mg} /$ day $)$ for the treatment of invasive candidiasis and that it would be advisable, in our opinion, to propose PK/PD studies to patients in whom a lack of clinical or microbiological efficacy due to a suboptimal dose of treatment is suspected.

\section{Authors' contributions}

AA conceived the letter and drafted the manuscript. LC, EH, MS, and AG drafted the manuscript. All authors read and approved the final manuscript.

Ethics approval and consent participate Not applicable.

\section{Competing interests}

The authors declare that they have no competing interests.

\section{Publisher's Note}

Springer Nature remains neutral with regard to jurisdictional claims in published maps and institutional affiliations.

Received: 7 May 2018 Accepted: 16 May 2018

Published online: 05 June 2018

\footnotetext{
References

1. Maseda E, Grau S, Luque S, et al. Population pharmacokinetics/ pharmacodynamics of micafungin against Candida species in obese, critically ill, and morbidly obese critically ill patients. Crit Care. 2018;22:94.

2. García de Lorenzo A, Luque S, Grau S, et al. Comparative population plasma and tissue pharmacokinetics of micafungin in critically ill patients with
} 
severe burn injuries and patients with complicated intra-abdominal infection. Antimicrob Agents Chemother. 2016;60:5914-21.

3. Grau S, Luque S, Campillo N, et al. Plasma and peritoneal fluid population pharmacokinetics of micafungin in post-surgical patients with severe peritonitis. J Antimicrob Chemother. 2015;70:2854-61.

4. Jullien V, Azoulay E, Schwebel C, et al. Population pharmacokinetics of micafungin in ICU patients with sepsis and mechanical ventilation. J Antimicrob Chemother. 2017;72:181-9. 